\title{
ART
}

\section{БАГАТОВИМІРНІСТЬ ВТІЛЕНЬ СЮЖЕТУ ТУРАНДОТ В ЖАНРІ ТЕАТРАЛЬНОЇ МУЗИКИ}

\author{
аспірант Ванг Юй \\ Львівська начіональна музична академія імені Миколи Лисенка, кафедра історії музики \\ Украӥна, Львів.
}

\section{DOI: https://doi.org/10.31435/rsglobal_ws/31032019/6419}

\section{ARTICLE INFO}

Received: 24 January 2019

Accepted: 16 March 2019

Published: 31 March 2019

\section{KEYWORDS}

Turandot, orientalism, theatrical music, J.C. Gillier, K.M. Weber, V. Lyachner, F. Buzoni, W. Stenhammar,

W. Ferst

D. Hosalla,

Y. Lakner,

A. Schnitke,

M. Denisenko.

\begin{abstract}
The article deals with the historical projection of the 300-year-old path of the Turandot image in the genre of theatrical music. After completing all the stages of European exoticism in Chinese subjects, Turandot was embodied in the main stages of the development of musical drama - from the baroque French Fair Theater Fory Saint-Lauren (Le Sage / d'Orneval for the first time analyzed music by J.C. Gillier) through the pre-classical model of Italian folk (K. Gozzi) to the concept of German romanticism (F. Schiller - F. Destush, K.M. Weber, W. Lyahner), oriental readings of the early modern days: neoclassical (F. Buzoni), symbolist (W. Ferst), primitive-naive (Y. Vakhtangov), psychologically-expressionistic (W. Stenhammar), household-entertaining variants (Broadway Theater) and complex multicomponent phenomena of the second half of the twentieth century, embodied in the "epic theater" (B. Brecht/ H. D. Hosalla, Y. Lakner, A. Schnitke) and means "Theater of absurd" (W. Hilderschmayer), based on postmodernistic parameters of hybrid genre formations in Ukrainian culture (M. Denisenko, I. Uryvskiy) in the globalized reference of intercultural communication of the beginning of the third millennium.
\end{abstract}

Citation: Wang Yuj. (2019) Multidimensionality of the Image of Turandot in the Genres of Theatrical Music. World Science. 3(43), Vol.3. doi: 10.31435/rsglobal_ws/31032019/6419

Copyright: (C) 2019 Wang Yuj. This is an open-access article distributed under the terms of the Creative Commons Attribution License (CC BY). The use, distribution or reproduction in other forums is permitted, provided the original author(s) or licensor are credited and that the original publication in this journal is cited, in accordance with accepted academic practice. No use, distribution or reproduction is permitted which does not comply with these terms.

Вступ. Досліджень, що стосуються образу принцеси Турандот в музиці є немало, та майже всі вони стосуються оперного втілення Дж. Пуччіні як найбільш виразного та популярного прочитання даного сюжету. Проте, лише побіжний аналіз та історичний дискурс появи і розвитку цього сюжету в мистецтві виявляє доволі значиму кількість різноманітних творів у різних жанрах європейських авторів різної національності. Це чи не єдиний 3 увиразнених китайських сюжетів, який ось уже більше 300 -років 3 різною інтенсивністю та динамікою втілюється на основі кількох літературно-драматичних моделей у музичному мистецтві. Але, фактично, крім опери Дж. Пуччіні, жоден 3 інших музичних творів (в тім - i численних оперних) не удостоївся окремого монографічного дослідження. Безперечно, що ці твори побіжно згадуються в контексті пуччінівської принцеси, як наприклад, у одній з останніх фундаментальних робіт В. Ашбрука та Г. Пауерса "Пуччінієвська Турандот: кінець великої традиції” [15], проте, черговий виток популяризації цього образу та поява нових інтерпретацій в Китаї, а також продовження адаптації сюжету в різноманітних жанрах, свідчать про зворотне. Зрештою, ні у вітчизняному, ні у світовому музикознавстві не було проведено чітко структурованого, 3 урахуванням диференціації жанрових різновидів, еволюційного шляху 
сюжету Турандот та його багатонаціональних ментально-специфічних прочитань у оперному, балетному, інструментальному та симфонічному жанрах. Також поза увагою залишилася об'ємна площина театральної музики, з якої і почав свій тріумфальний хід образ Турандот.

Мета дослідження полягає у спробі не лише комплексно розглянути музичні прочитання сюжету Турандот у сфері театральної музики, але синхронізувати їх у стилістичночасовому континуумі з урахуванням геокультурних маршрутів їх поширення та втілень історії про китайську принцесу у різноманітних видах та жанрах театрально-музичного мистецтва, співвідносно з процесами розвитку орієнталізму в європейському музичному мистецтві.

Результати дослідження. Витоки появи цього образу зустрічаються в поемі Нізамі “Сім красунь” (“Райф-Пейкар”), в якій рисами майбутньої ще ненародженої Турандот наділена одна 3 семи красунь - слов'янська. Її знаками є червоний колір, планета Марс, камінь рубін, небувалий інтелект, завдяки якому вона вибудовує неприступну технічно досконалу фортецю, здобуваючи яку, претенденти на руку принцеси гинули, і лише один, який не лише подолав технічні складності, але й відгадав хитромудрі загадки слов'янської принцеси щасливо одружився з нею. Китайська ж - навпаки (жовтий колір, золото, Сонце, погідність, покірність, делікатність) є іiї абсолютною протилежністю [7]. Французький мандрівник Петі де ля Круа, пробивши у Персії всього два роки, ознайомився 3 поемою Нізамі. Згодом перебрався до Туреччини, де захопився казками “Тисячі і одної ночі". Після повернення до Франції у 1710 p. видає збірник орієнтальних оповідок під назвою “Тисяча і один день” (перверзія “1001 ночі”), в якій розміщено казку про китайську принцесу Турандот (de la Croix François Pétis "Histoire du prince Calaf et de la princesse de la Chine".Les mille et un jours contes persans, turcs et chinois). Так народжується новий літературний персонаж, який користується популярністю у французьких читачів, здобуваючи зовсім незадовго у 1729 р. своє перше музично-сценічне втілення. Дослідження етимології імені Турандот виявило кілька варіантів, пов'язаних 3 перськоіранською традицією - давньою народністю туран (від доньки Турана за А. Кримським [5]), якою у Нізамі головний герой поеми Райф Пейкар мріяв заволодіти територією цього народу і називав себе спадкоємцем Турану. Пошуки дослідників походження цієї загадкової особи і аналогій щодо сюжету пов'язаного з загадками та стратою наречених-невдах висвітлено у праці “Сестри Турандот" К. Гольдберг [21].

В європейській інтерпретації Турандот стає китайською принцесою, вочевидь, як данина тодішній моді на “китайщину”, яка інтенсифікувалася в добу високого бароко. Ця тема піднімається у праці Адріани Вард [33], в якій авторка налічує впродовж XVII ст. близько 70-ти зразків опер найрізноманітніших жанрів 3 китайською тематикою, серед авторів яких А. Філідор, Ж.-Б. Мато, Ф. Гаспаріні, Ж.-К. Жільє, А. Кальдара, Ж.-Ф. Рамо, А. Скарлятті, Г. Пуньяні, Г. Агріколі, Й. Хассе, Б. Галюппі, Д. Чімароза та інші. Приходячи в театр через тогочасні масові розважальні акції - маскаради і карнавали, китайська тема стає популярною і в музичному театрі, причому в різних жанрах: від комедії, арлекініади, водевілю, комічної опери, інтермеццо до dramma per musica, музичної драми, трагедії та ін., виставляючись, практично, по всій Свропі - у Неаполі, Парижі, Лондоні, Мілані, Венеції, Модені, Зальцбурзі та ін.

Після появи збірника орієнтальних казок «1000 і один день» Петі де ля Круа, першими, хто підхопив ініціативу адаптації сюжету про принцесу Турандот, ім'я якої виникло з волі автора оповідки, стали два популярні драматурги, які працювали у сценічних жанрах простонародного ярмакового театру Форі - Анрі-Рене лє Саж і Філіпп д'Орневаль. В 1729 р. вони пишуть невибагливу п'єсу, яка з успіхом була поставлена під назвою «Китайська принцеса» у театрі Форі Сен-Лоран. Так, новонароджена в ореолі казкової містики Турандот потрапляє в бурхливу масу розважальної індустрії XVII століття. Першим композитором, який “озвучив” сюжет китайської принцеси став композитор Жан-Клод Жільє (Gillier) ${ }^{1}$. Дж. Кукуел у роботі “Творці французької "Опера-Комік" [18, 35-36] подає наступну інформацію: “Жан-Клод Жільє (1667-1737) працював музикантом в капелі короля і був одним з кращих скрипалів, згодом грав у оркестрі камерної музики герцога Орлеанського. В 1690-1715 Ж.-К. Жільє був одним з провідних композиторів Комеді Франсез. 31715 р. він перейшов у Опера Комік, де залишився на службі до смерті в

\footnotetext{
1 Зауважимо, що до появи "Китайської принцеси" лє Саж та Жільє успішно виставляли у театрі Форі Сен-Лоран ще у 1713 році 1-актний водевіль “Невидимий Арлекін короля Китаю” (він значиться і в постановках цього театру і за 1720 р.), тобто, досвід втілення псевдо-китайської тематики ці автори вже мали. Зрештою, всюдисутній Арлекін, мандри якого відтворювалися в тодішніх постановках був своєрідним провідником у екзотичні далекі країни, захоплюючи в поле своєї діяльності доволі широку географічну перспективу [33]
} 
1737 p. Тобто, більшість музичних творів, що містяться в театрі Сен-Лоран належать саме йому" [18]. Більше як 20 років він був музичним директором, капельмейстером та балетмейстером Театру Сен-Лоран, автором музики щонайменше до 81 вистави (за даними фондів бібліотеки університету Стенфорду http://operadata.stanford.edu/catalog/10111929). Нещодавнє оцифрування архівів Театру Сен-Лоран дозволило не лише детально вивчити саму п'єсу з усіма "музичними ремарками", але й сприяло оприлюдненню вокальних та інструментальних зразків першого музичного прочитання сюжету про китайську принцесу, яка, як виявилося, не носить імені Турандот, натомість названа у цій п'єсі Діамантовою Принцесою Китаю. Так, п'єса в трьох актах "La Princesse de la Chine" з зазначеними ініціалами лє Сажа та д'Орневаля " вміщає у томі 7 i об'ємні нотні додатки [26], що дозволяє розглянути власне музичне першопрочитання сюжету Турандот. Зупинимося докладніше на основних музичних моментах вистави.

Коло персонажів вистави досить численне, хоч фабула розігрується між трьома основними силами - це китайський король Альтоум (з представниками знаті, офіцерами, солдатами, катами, мандаринами та верховним жерцем Колао і священнослужителями), його донька - Діамантова Принцеса Китаю (з власним дівочим почетом-балетом та представницями Ельмазі, Діляра), мандрівний принц Нореддін (зі своїм ад'ютантом-другом П'єро), страчений на початку п'єси принц Бахраму та типові маскові персонажі - Скарамуш (придворний художник) та Арлєкін (придворний балетмейстер 3 великою танцювальною трупою), а також два символічні персонажі - Любов і Гіменей, які виступають під кінець вистави у заключному мораліте. Так, закладається основне коло персонажів - модель фабули, яка в майбутньому буде працювати у образно-подієвій сфері Турандот, змінюючись, модифікуючись, долучаючи або віднімаючи певні персонажі (в тім супутні або й контробрази), однак, зберігаючи три основні драматургічні лінії - короля, свавільної жорстокої принцеси і мандрівного принца.

В тексті п'єси зазначено, що всі герої п'єси співають невеличкі арії (переважно по куплету) на різні попередньо відомі мотиви, назви яких щоразу вказуються в дужках біля слова Арія відповідного персонажу. I лише деякі з них є спеціально написаними для цієї вистави (переважно авторства Ж.-К. Жільє). Такими ж позначеннями виділено танцювальні фрагменти, і майже відсутні ансамблі та хори (дуетні номери постають як театральні діалоги, де кожен наділений сольною партією, а хор, порівняно з танцювальними номерами, виступає в дуже обмежених епізодах (сцена загадок та фінал). Натомість інструментально-танцювальні фрагменти відіграють доволі суттєве значення, отримуючи навіть свого речника балетмейстера китайського королівського двору Арлекіна.

Першим яскравим епізодом, який відтворював би китайську атмосферу та наділений екзотичним елементом стає звучання кроталів (мініатюрних тарілочок) та китайських тамбуринів за сценою. В жалібній процесії походу Принца Бахрама на страту ідуть солдати, кати, охоронці та офіцери. Скорботний жалібний марш у виконанні оркестру супроводжує процесію. Це абсолютно стилізована музика, позначена як "Марш дракона", де єдиним екзотичним штрихом $є$ використання цих інструментів, а після вироку Марш стає дедалі сумнішим (ремарка авторів), очевидно, відбувається зміна ладу - невибаглива мелодія в Ремажорі переходить в ре-мінор). Згодом, Ельмазі розповідає Нореддіну про красу Принцеси Китаю, характеризуючи ії в Арієї на мотив “Шарман Габрієль” (І Акт, Сцена 6), а далі на мотив Арії №67 продовжує захоплену розповідь про красуню (мотив з Водевілю “Новий Місяць”). 3-за сцени вперше долинає спів Принцеси і чудовий голос ще більше розохочує Норредіна. Ельмазі танцює, демонструючи рухи придворних танцівниць і врешті показує портрет Принцеси, в який Норредін безоглядно закохується. П'єро, виконуючи Арію 3 п'єси на східний сюжет “Принц Помаранчів”, пояснює меланхолію Нореддіна як закоханість (І Акт. Сцена 10).

Величний похід проходить у напрямку до сакраментального священничого саду, де відбуватиметься жертвоприношення бонз, які складають на вівтар під поважний похід та Арію головного бонзи при хоровій підтримці урочисті гімни (саме коло цього номера значиться авторство Ж.-К.Жільє (“Арії № 73 і 74 належать м-є Жільє”). Цією прославною сценою величання, сповненої екзотичних костюмів, розмаїтих аксесуарів, квітів та запахів, як i належить при прославленні китайської імперії, закінчується I Акт (Сцена 11) автори намагалися відтворити східний екзотичний колорит.

У Священному саду (II Акт) король Альтоум і верховний жрець Колао вирішують відмовити Норредіна від його намірів здобути руку Діамантової Принцеси. Ця величезна сцена йде у демонстрації кількох арій, пов'язаних з демонічними силами (II Акт, Сцена 13). Кілька вокальних Арій проходять у танцювальних варіантах (Гавоту, Мюзету та Менуету) дівчатпосланниць Діамантової Принцеси, які після великої сцени з Нореддіном спішать до неї з 
новинами про бажання Нореддіна відгадувати загадки (II Акт, Сцена 19). Двоє 3 дівчат Ельмазі і Діляра залишаються самі, оточені лише придворними танцівниками, які під супровід їх двох Арій (Ельмазі - №102 - на музику Ж.-К. Жільє та Діляра - № 103 - на мелодію “Меме”) роздумують про розв'язання майбутніх подій (закінчення II Акту, Сцена 20).

В садах Королівського палацу Король Китаю і Норредін ще раз обговорюють проблему випробувань і Принц просить скликати Альтоума Диван. Чотири вокальних соло - Арій Короля побудовані на різних мелодіях, а у №104 вказано темп - Vivo на тему Мішель Нострадамус (III Акт, Сцена 21). Після цього Норредін залишається сам і дуже хвилюється, закликаючи на допомогу Магомета, співаючи невелику драматичну Арію (III Акт, Сцена 22), ймовірний прообраз знаменитої пуччінієвської Nessum Dorma. 3'являється Скарамуш - придворний художник, який пише портрет Норредіна за Королівським наказом для поповнення галереї Принцеси, при цьому Скарамуш співає кілька Арій на популярні мотиви. (III Акт, Сцена 23).

У аспекті танцювального елементу є цікавою Сцена 24 з III Акту. Арлекін - директор королівського балету, який стає ведучим персонажем у цій сцені, виходить 3 танцівниками $\mathrm{i}$ навчає Норредіна спеціальних нових балетних рухів, для того аби той гідно постав перед Діамантовою Принцесою. Вихваляючи свій балет та силу і красномовність танцю у кількох вокальних Аріях, що супроводжуються демонстрацією нових рухів, сцена закінчується двома балетними Фантазіями під супровід оркестру. При цьому робиться помітка, що в італійських виставах буває лише одна танцювальна сцена, тут же присутні дві - перша 3 яких - морська (про подорож героя), друга - церемоніально-урочиста, придворна, в якій прославляються Любов і Гіменей - два символічні персонажі вистави (III Акт, Сцена 24).

У наступній Сцені 25 з III акту П'єро намагається підтримати Принца Норредіна і описує у своїх невеликих Аріях його хвилювання, закоханість в портрет Принцеси Китаю. Натомість, у випадку загибелі, Нореддін просить вірного П'єро запам'ятати і розповісти людям його історію у кількох невеликих прощальних Аріях на різні мотиви. Надходить Колао, який повідомляє, що Диван зібрано і пора рушати. Під звуки Маршу Нореддін відходить (Сцена 26, III Акт).

Найбільш розгорненими та масштабними є три фінальні Сцени 27-29 3 III Акту відгадування загадок. Велична округла Тронна Зала, де в глибині пообіч знаходиться два тронні крісла - Короля Китаю і Принцеси, від них, півколами розміщуються місця радників Великого Дивану. Повільно і урочисто входять на сцену Король Китаю у супроводі Мандаринів, солдат, знаті з одного боку, з іншого - Діамантова Принцеса зі своїм танцювальним кортежем. Коротке вітання Короля 3 Донькою, яка показує і протанцьовує перед Батьком нові фігури закінчує цю сцену. Принц Нореддін, П'єро та Колао стають перед лицем Діамантової Принцеси. Як i попередньо - Мандарин та Принцеса задають свої загадки за допомогою невеликих Арій, i такими ж невеликими музичними вокальними номерами їй відповідає Принц Нореддін. Музичний матеріал береться 3 добре відомих публіці музичних номерів, в яких співається про ту чи іншу загадку (iї зміст чи натяк на розгадку), що надає цілому характеру музичної вікторини (III Акт, Сцена 28). Отож, після фанфар, які оголошують початок змагання, Мандарин, вторячи їм, починає акцію. Церемоніал продовжує Принцеса, яка бажає успіху молодому мандрівникові (на мелодію “Подорожі турецького паші”) - і Нореддін відповідає ій (відспівуючи популярною мелодією “Коли небезка чигає на тебе, то покладайся на Любов.”) У цій сцені, попри аріозні моменти, є багато реплік та коротких діалогів. Наприклад, постійним фоном йдуть репліки П'єро, який хвилюється за свого господаря. Король перемовляється 3 Принцесою між загадками. Пантоміма зображає Першу Енігму. Це відблиски невловимого Світла (Арія Принцеси на темі “Нової Джоконди", Нореддіна - на попредніх інтонаціях). Реагують ствердно Коало, Мандарини, П'єро і хор. Друга Енігма - про Очі, які здатні побачити більше за світло з наступною реакцією хору. Третя Енігма - це Людина, яка є мірилом всього. Після загального захоплення відгадками Принца, Діамантова Принцеса, обмінявшись репліками з Королем та Нореддіном з пишнотою та в передчутті весілля під урочистий Марш покидають Тронну Залу.

У Фіналі (Сцена 29 III Акту- остання) Арлєкін виводить на сцену всю балетну та театральну трупу, хор, зодягнений у розмаїті національні костюми, підкреслює ідею мандрівок. У Арії (тут пропонується кілька варіантів мелодій) Арлекін підводить підсумки вистави. Кожен сольний номер є підтримуваний балетом і хором. Далі звучить Арія Любові (знову на кілька мелодій за вибором) i врешті остаточні куплети Гіменея, які увінчують п'єсу. У цій Арії №117 позначено нову, спеціально написану музику Ж.-К. Жільє - Фінальні куплети, приспів яких за кожним разом підтримує хор мандрівників. Це резюме 3 коротким викладом змісту, де в останньому, шостому куплеті Гіменей звертається до публіки, виголошуючи моральні сентенції вистави [26]. 
Таким чином, перша постановка на тему Принцеси Китаю, що відбулася у ярмарковому театрі Форі Сен-Лорен, єднає в собі різноманітні різножанрові риси і по-суті проектує подальші жанрові втілення та модифікації. Особливостями цього типу театру були захоплюючі видовищні постановки з багатою сценічною обставою та вражаючим костюмованим рядом. У імпровізовані сцени-інтермедії включалися музичні інструментальні та вокальні номери, рівно ж - великого значення набував танцювальний елемент. Так, ярмарковий французький театр поєднував риси комічної опери, театрального дійства та балету $[32,25,27,22,16,14]$. Східні та екзотичні сюжети оздоблювалися широким діапазоном ефектів, непомірно збуджували фантазію, аби на невеликих та скромно оснащених сценах створювати численні зміни декорацій, ілюструвати природні катаклізми, дію магічних засобів або ж просто відтворювати невидану розкіш казкових країн [9]. Діалог «низового» та офіційного театру перебував в активно-конкурентній стадії, а своїй суперниці, Комеді Франсез, ярмарка принесла величезну користь, підштовхуючи ії до експериментів, показуючи приклад мобільного театру, який перебуває в постійному русі, оновленні репертуару. Конкуренція була настільки гострою, що Комеді Франсез в боротьбі за глядача змушена була переймати від суперниці тричастинну форму спектаклю, дивертисменти, сценічні ефекти, оригінальні сюжети, жанрові міксти, дозволяючи фарсовому духові проникати в свої комедії. Так, перша Діамантова Принцеса Китаю - майбутня Турандот - була вирішена саме в дусі традицій ярмаркового театру i справляла відповідне враження завдяки екзотичним сценічним ефектам. Примітно, що в цій постановці на псевдо-китайський сюжет фігурують не лише запозичені з інших вистав мелодії східно-орієнтального типу, але й голландські та шведські танці, представляючи країни женихів, які змагаються за руку жорстокої принцеси. Таким чином, переміщаючи “прописку” у Китай, Турандот, прообраз якої народився у персидській літературі (у поему Нізамі включена надзвичайно широка поліетнічна панорама), збагатившись елементами турецьких казок, збирає довкіл себе щораз більше геокультурне коло, в тім - стилізованих ознак європейських народів.

В подальшому (через 33 роки) Турандот, зберігаючи власне ім'я, націоналізується італійським драматургом Карло Гоцці, який привносить у свою фаволу (казку) не лише італійські персонажі commedia dellarte (Брігелла, Труфальдіно, Панталоне) та суто італійські деталі (третя загадка стосується крилатого Лева Адрії - символу Венеції), але й розширює дотичну географію за рахунок символів Венеції (рідне місто К.Гоцці та великого мандрівника Марко Поло зі справді нещасливим коханням до китайської принцеси), вводячи в сюжет такі топонімічні території як Кавказ, Ногай, Татарію, Астрахань та інші країни [2]. Вочевидь, запрограмована як гібридна версія, ця сюжетна лінія, в центрі якої знаходиться принцеса Турандот, яку можна вважати однією з родоначальниць шинуазрі, виявляє доволі потужні властивості до схрещування, а селекціонування окремих видів чи моделей власне самої героїні та ії сюжетного полінаціонального оточення можна трактувати як "прирощення" різнорідних елементів (“щеплена химера") до такого ж нереального вигаданого казкового персонажу. Щодо музики до цієї популярної ф'яби (фаволи) К. Гоцці, то автора наразі не вдалося встановити. Ії прем'єра 3 великим успіхом відбулася у Венеції в театрі Сан-Самуелє 22.01.1762 p. Ремарки відносно музичних номерів позначені у тексті фаволи самим К. Гоцці: це дріб барабанів при страті претендентів на руку Турандот - принца Самаркандського і принца Татарського у I дії; урочистий Марш виходу 8 китайських мудреців на початку II картини I дії; у IV картині II дії, яка відбувається “без слів” у мімансі, Марш з тамбуринами супроводжує похід знаті і рабів, а після підготовки до сцени відгадування загадок він же і завершує похід цієї картини. Цей або інший Марш також з тамбуринами завершує II дію (після відгадування загадок). У картині II з V дії жалібну процесію Турандот супроводжує Траурний Марш [2]. Можна припустити, що Гоцці скористався принагідними фрагментами музики різних композиторів (такі версії були прийнятними для тогочасного театру), однак, вказівки на точно використані інструменти (барабани, тамбурини) ставить під сумнів це припущення. У Сан-Самуеле ж на цей час була затруднена театральна трупа родини Саккі, ймовірно, хтось із них виконував і роль штатного композитора [33].

На зорі XIX ст. Турандот потрапляє під увагу видатного німецького драматурга Ф. Шіллєра, який адаптував ф'ябу Гоцці у новій романтичній манері. Драматургія Гоцці була добре відомою в Німеччині не лише крізь призму всюдисутніх італійських театрів, але й існували німецькомовні переклади його п'єс, наприклад, Ф. Вертрса 1779 р., якf поширилися в літературних колах. Гостродраматичний сюжет та емоційна насиченість образу китайської принцеси відповідали тенднціям формування романтичної естетики. У адаптації Ф. Шіллєра Турандот по-суті трансформувалася у його власну драматичну версію. При підтримці і заохоченні Й. В. Гете, який ініціював створення яскравої орієнтальної п'єси для оновлення Ваймарського театру, вона з'явилася взимку 1801-1802 рр. під назвою “Турандот, принцеса Китаю”. Так, при зусиллі двох найбільших 
літературних талантів епохи народилася нова Турандот. Ф. Шіллєр дотримався загальної конструкції п'єси Гоцці, проте, значно глибше розкрив психологічні аспекти героїні та ситуацій довкола неї. Він повністю позбавляється венеційського дель'артового колориту, переводячи п'єсу 3 пригодницької трагікомедії у ранг персональної романтичної драми. Шіллєрівська Турандот стає трагічною героїнею, а тема кохання Калафа має значно глибше коріння, аніж раптове захоплення. Змінює Ф. Шіллєр і орієнтальний колорит,, прагнучи надати цьому сюжетові хоча б відносної китайської автентичності [13].

Початково від 1804 р. п'єса Ф. Шіллєра йшла з музикою Франца Серафа фон Дестуша (1772-1842) - австрійського композитора і відомого віолончеліста, який отримав музичну освіту разом з Й. Гайдном, працював віолончелістом у капелі Естерхазі та був концертуючим піаністом, згодом - капельмейстер в капелі герцога Ваймарського. У Ваймарі він написав музику до кількох п'єс Ф.Шіллєра (“Табір Валленштайна", “Орлеанська діва”, “Мессінська Наречена", "Вільгельм Телль” і “Турандот”), .до кожної з яких створив не лише театральні музичні номери, але й чудові увертюри (за Ф.Фетісом - m.3 c.10) [20]. Наразі це всі дані про дане музичне оформлення п'єси.

Для прем'єри перекладу Ф. Шіллера у 1809 р. Карл Марія фон Вебер також написав музику до цієї вистави: Увертюру та шість інструментальних фрагментів: “Марш” (№2); "Урочистий марш" (Marcia maestoso) (№3); три епізоди “Moderato” (№o 4-7); “Жалібний марш” (Marcia funebre) (№7). Музичний матеріал засновано на псевдо-східній темі зі “Словника" Ж.-Ж. Руссо, яка отримала назву “повітряний Китай”; в основі якої пентатоновий ладовий нахил. Ця тема стала своєрідним кліше мелодій у китайському стилі. Вебер втілив ії елементи у кожній з частин, застосовуючи цю тему як наскрізне об'єднуюче начало впродовж вистави. Найбільш яскравим музичним зразком з театральної музики К.-М. Вебера до цієї п'єси $\epsilon$ Увертюра, яка не так давно отримала своє “друге життя" в звуковому просторі, поповнюючи яскравий та багаточисленний корпус оперних симфонічних увертюр, які, з виходом за межі сценічних жанрів ведуть активне концертне життя. 3 плином часу та появою все нових творів і трактовок сюжету “Турандот”, ця музика стала призабутою, а до ії відродження спричинився в середині XX-го ст. П. Гіндеміт, використавши тему “air chinois" у Симфонічних "Метаморфозах" на теми Вебера (1944), де одна з частин Скерцо - має назву "Турандот" і початково призначалася для втілення в балетній постановці Л. Мясіна.

Звертався до драми Ф.Шіллєра “Турандот" і Йозеф Блюменталь (1782-1850) - блискучий скрипаль бельгійського походження, який навчався у Празі, згодом у Відні у абата Фоглєра. Дебютував оперою “Саморі” у 1803 р. у Відні, яка принесла йому великий успіх. С автором двох опер: 4-актна романтична опера “Дон Сільвіо де Розальба" та двоактна феєрія "Коротке манто". Вважався одним з найяскравіших творців театральної музики, а серед його робіт - музика до драм “Колумб”, “Король Лір”, “Катерина Деліброн”, “Фернан Кортез”, “Турандот” до п'єси Ф. Шіллєра. [20, C.449-450 ], однак ноти до цієї постановки поки не знайдені.

В середині XIX ст. до теми Турандот у жанрі теаральної музики звертається Вінценз Ляхнер (1811-1893) [29]. Один з трьох братів Ляхнерів - близьких друзів Ф. Мендельсона, К. і Р. Шумана, сподвижників Й. Брамса, Вінценз починав кар'єру у Відні, де уславився як капельмейстер, композитор та контратенор Віденської опери. Закінчив творчий шлях у Карлсруе, де 31872 р. викладав у консерваторії. Інцедентальна музика до драми Ф. Шіллєра “Турандот” ор.33 була створена В. Ляхнером у Мангаймі, де він був диригентом та капельмейстером оперного театру з 1936 по 1842 pp. У 1860 р. Увертюра отримала дворучний фортепіанний переклад Гекеля, а у 1865 p. Увертюра і Марш “Турандот” були видані у Ляйпцігу. 3 цієї музики залишилось лише 2 номери - розгорнена симфонічна Увертюра та Вступний марш, композиція якого нагадує сюїтний принцип побудови, очевидно, призначений до виходу китайського двору. Зазначимо, однак, що музичне оформлення В. Ляхнера, пронизане піднесеними романтичними темами, хоч і не наділене яскравими орієнтальними рисами, та передає, радше, шіллєрівську психологічну концепцію, узагальнює лірикоромантичну лінію.

Так, вигаданий європейцем персонаж Турандот отримав музично-сценічне прочитання у жанрі музики до театру у Франції, Італії, Німеччині, Австрії, згодом, все більше розширяючи геокультурну амплітуду, демонструючи специфічні риси барокового, класичного та романтичного орієнталізму. Новим витком, попри численні оперні прочитання у XIX ст., які й засвідчують інтерес до цієї теми та відповідають тенденціям романтичного екзотизму, стає модернове прочитання сюжету одним 3 непересічних і найцікавіших композиторів Свропи першої третини XX ст. - Феручо Бузоні. 
Зацікавленість Феруцо Бузоні на зорі ХХ ст. сюжетом Гоцці становить окрему сторінку в ракурсі даної тематики. Захоплення цією темою виявилося і у фортепіанному циклі "Елегії. Сім нових п'єс" (1907), де під № 4 є композиція під назвою “Покої Турандот" (Інтермеццо). Над музикою до п'єси Гоцці він почав працювати ще у 1904-1905 pp. Це був період роботи композитора 3 режисером Максом Рейнхардтом, проте перша спроба виявилася невдалою (Бузоні відмовився зменшувати склад оркестру: 60 музикантів, а завеликий і закоштовний для бюджету театру проект не був реалізований). Для постановки п'єси Гоцці Бузоні замовив німецьку версію італійського тексту у письменника Карла Вольмюллєра. Паралельно 3 безпосередньою музикою до п'єси композитор створює оркестрову Сюїту у восьми частинах op.41, яка активно і успішно виконувалась як симфонічний твір. У 1911 році композитор дописав "Verzweiflung und Ergebung" (“Відчай і відставка"), що мав виконуватися між IV i V діями; він також додав його між 7 і 8 номером вже до відомої однойменної оркестрової сюїти. Вкажемо назви 8-ми головних номерів до казки К. Гоцці "Турандот" Ф. Бузоні 3 доданими згодом частинами (опублікованих у 1906): №1 Вступ "Міські ворота"; №2 "Труффальдіно": Вступ і гротескний марш; №3 Марш Альтума; №4 Марш Турандот; №5 Вступ до III акту; №6 Танець і пісня; №7 "Нічний вальс" з IV акту (додана); №8 “Відчай і відставка" - перегра між IV i V актами (додана); №9 "В стилі похоронного маршу" (згодом Бузоні замінив його на “Попередження Альтума" в 1917); №10 “Турецький фінал”[4].

"Турандот" Гоцці, адаптована К. Вольмюллером 3 музикою Ф. Бузоні була поставлена у Німецькому театрі в Берліні, 27.10.1911 р., 3 потрійним складом оркестру під батутою Оскара Фріда. Цій виставі було присвячено окремий випуск театрального часопису "Blätter des Deutschen Theaters”, де були розміщені інтерв’ю та матеріали Ф. Бузоні, Е.Орліка, відгук письменника С. Цвайга. Дж. Пуччіні писав про цікаві мізансцени: "У виставі Рейнхардта «Турандот» була крихітною жінкою в оточенні високих чоловіків, спеціально підібраних за зростом; величезні стільці, величезні меблі, і між ними ця малесенька гадюка-жінка 3 дивним серцем істерички” [17, 351]. Додамо, що рясна критика відзначала надзвичайну красу, силу і потужність музики Ф. Бузоні, яка очевидно превалювала над сценічною дією. В контексті дослідження додамо, що композитор невдовзі створив оперу на власний текст “Турандот”, прем'єра якої відбулася у 1917 р. Створюючи орієнтальну казку, Ф. Бузоні в своїх намірах виходить за межі китайщини, будуючи свій тематизм не лише на матеріалі китайського, перського, турецького та індійського походження, використовуючи в якості першоджерела "Історію стародавньої музики" видатного музиколога А. Амброса, де у I томі вміщено численні зразки східних мелодій, адже композитор припускав, що Турандот зовсім не китайська принцеса, радше, персидська. Ймовірно, що саме цей композитор як один 3 яскравих неокласиків намагається розширити звуковий ареал прочитання теми, хоча залишає в “зовнішніх" межах цей образ як китайської принцеси.

Нове прочитання "Турандот” з'явилося незабаром в творчості американського драматурга Персі МакКея (1875-1956) у його п'єсі “A Thousand Years Ago. A Romance of the Orient” [28] для постановки на Бродвеї у 1914 р. 3 музикою Вільяма Ферста (1872-1917) - американського композитора, аранжувальника, довголітнього директора театру на Бродвеї (за даними видання п'єси МакКея). Отже, Турандот знайшла своє місце в мистецтві мюзиклу. Варто зазначити, що в кількох джерелах є інформація про адаптацію музики В. Ферстом до цього мюзиклу, проте, опера Дж.Пуччіні ще не була написана у 1914 р. Вочевидь, В. Ферст (остання його робота датується 1913 роком) скомпілював музику зі своїх численних постановок, тим більше, що у його творчому доробку уже звучали стилізовані в бродвейському дусі і китайська, і персидська теми (“Троянда Персії” та “Жовті маринарки”). I хоча китайська екзотична тема уже обігрувалася у американському театрі - саме Турандот знаходить своє втілення у жанрі мюзиклу на початку XX століття. У тексті та ремарках п'єси знаходимо вказівки щодо окремих музичних деталей, наприклад, стилізація музикування чотирьох дельартових персонажів: Арлєкіна, П'єро, Труффальдіно, Панталоне, перший з яких грає на мандоліні, а інші виконують танцювальну сцену. Музика до цієї вистави не збережена, хоч у ремарках знаходимо посилання на традиційні для цього сюжету марші, процесії та низку вокальних номерів. Особливо є цікава балетна кількарівнева сцена садів Турандот, вирішена за допомогою світло-музичних ефектів.

Шведський композитор Вільгельм Стенхаммар (1871-1927) написав досить оригінальну музику для постановки ф'яби К. Гоцці “Турандот” у Стокгольмському Королівському театрі у 1920-му році. "Музика до вистави “Турандот" ор. 42 вирішена для досить незвичного складу інструментів: флейти, кларнета, фагота та перкусії (трикутник, цимбали, бас-барабан і там-там) i включає вісім рівнозначних частин: №1 "Вбивчі барабани”; №2 "Портрет Принцеси”; №3 "Вихід Імператора”; №4 “Вихід Принцеси”; №5 “Марш”; №6 “Леви Сан Марко”; №7 “Заключний Марш”; 
№9 “Фінал Турандот”. Специфічна оркестровка дещо нагадує пошуки І.Стравінського у сфері театральної музики, який довільно моделює камерними складами інструментів. Написана яскраво авангардними засобами на межі додекафонії та атоналізму, найбільш оригінальна під оглядом саме інструментовки. Так, тема "Портрету Турандот" викладається соло фагота. Мелодична лінія, хоч і позначена ремаркою dolce, насичена дисонантними ходами, тяжіє до нерегулярної ритміки, яка передає внутрішню напругу, сум, непевність при загальному тривожному стані. Переважання зб. та зм. інтервалів, півтонові коливання, “слизькі” зсуви або навпаки розширені декламаційно виразні ходи гравітують до монологічного типу викладу. Можна визначити даний фрагмент, як спробу композитором схопити психотип непогамованої пристрастями, гордощами, в певному сенсі зі зрушеною психікою жінки-вбивці. Що ж, скандинавський нахил до специфічної похмурої “психоделіки” (Стріндберг, Бергман - тим більше, що Стенхаммар писав музику до їхніх п'єс) дається взнаки [6]. Таким чином, Турандот, при зовнішньому екзотизмі, щораз більше і глибше занурюється в ментальні прочитання, стаючи свого роду відбитком відповідних національних психотипів та їх реакції на особливість даного сюжету [23]. Східноазійська Турандот з китайським присмаком поширюється в північній зоні снігів та льодів, виходячи за межі центральної Свропи, зрештою, поступово починає рухатися на Схід, попередньо відвідавши далекий Американський континент. Наступною точкою адаптації Турандот стає Україна.

У 1921 р. в Харківському державному драматичному театрі з великим успіхом пройшла п'єса Гоцці “Турандот”, для якої написав музику молодий Ісаак Дунаєвський. Учень С. Богатирьова (композиція), К. Горського та І. Ахрона (скрипка) Дунаєвський починає працювати скрипалем і концертмейстером оркестру в цьому театрі, де в 1920 році дебютує як театральний композитор музикою до спектаклю Бомарше "Весілля Фігаро", а наступного року з'являється музика до вистави Гоцці “Турандот” в постановці режисера В. Синєльнікова. Риси мюзиклу і ліричної оперети з екзотичними нотами характеризують цю сповнену молодечої сили і чудових мелодій композицію І. Дунаєвського (за спогадами сучасників [12]), який став по-суті родоначальником радянської оперети. На жаль, збереглися лише афіші 3 постановки цієї вистави в Сімферополі (Крим), а ноти, як і з бродвейської постановки, наразі не знайдені.

Вже наступного, 1922 року відбувається “перезавантаження” п'єси Гоцці Євгенієм Вахтанговим у MXAT-ті в Росії, яка продемонструвала принципи нового ігрового театру. Режисер гостро відчував поетику ігрового театру, його легкість, імпровізаційність, відкриту умовність. Цим театром акцептуються витоки давніх джерел сцени, елементи народних ігрищ, балаганих вуличних вистав, маскарадів тощо. "Принцеса Турандот" стала символом народження нового типу "наївного" театру. "Ігровим способом створювалася і музика. Мотиви "Турандот" виникають самодіяльно. Вахтангов використовує власні “заготовки”, в тому числі і мелодію євпаторійського шарманщика, що нагадувала “Ласточку” відомого вірменського композитора Комітаса. У знайомих Вахтангова зберігалася старовинна музична китайська іграшка, першим власником якої був композитор О. Скрябін. Її звучання стало одним з музичних лейтмотивних знаків спектаклю. Також було використано і оркестрики з ігор Сулержицького, і знамениті популярні того часу “співаючі" гребінці” з постановок Мейєрхольда. На одній з репетицій П. Антокольський на прохання Вахтангова складає слова наївної пісеньки - "Вот мы начинаем этой песенкой простой...”. Музиканти оркестру Ніколай Сізов і Анатолій Козловський підбирають нескладний, майже примітивний мотив...” [8, С.341] Тобто, нові явища кітчу, імпровізації, характерні для музичного оформлення спектаклів XX-го століття заторкнули і Турандот. Збереглося кілька музичних номерів з цієї постановки: №1. “Марш”, музика Н. Сізова; №2. "Вальс Турандот" - музика А. Козловського; №3. "Пісенька" - музика Н. Сізова (на популярний мотив галопу “Кур'єрський поїзд” Франца Бауэра, написаного ще 1800 р.), сл. П. Антокольского; №4. "Полька цанні” Н. Сізова. Варто зауважити, що музичні номери 3 цієї постановки здобули величезну популярність у пуліки, блискавично поширюючись, увійшли в міський побут і вважалися свого роду “хітами” у першій половині XX ст. Героїня ж Гоцці настільки прижилася на російському грунті, що навіть отримала специфічне топонімічне втілення. “Знаменитий Вальс Турандот став музичним символом російського театру загалом. Ця музика достойна створення особливого пам'ятника поруч з фонтаном Турандот на старому Арбаті" [8, С.349]. I дійсно, росіяни поставили пам'ятник цій літературній героїні, а фігурка "Кришталевої Турандот" стала своєрідною нагородою-Оскаром російського театру.

Новим витком у розвитку теми Турандот стає оригінальна п'єса знаменитого німецького драматурга Бертольда Брехта “Турандот або Конгрес вибілювачів", для якого трактовки i К. Гоцці, і Ф. Шіллєра стали лише однією $з$ ідей для створення абсолютно нової концепції, щоправда зі збереженням сталої фабули - загадок та відрубування голів. Однак, героїня стає 
невільницею політичної системи і зброєю-маріонеткою в руках батька-імператора, що суттєво зміщує акценти у даному сюжеті. Введення низки нових персонажів - туалів - сучасних інтелектуалів, яким власне і присвячена п'єса, доводить, що сюжет Турандот інспірував появу нової власної авторської концепції [1]. П'єса була поставлена після смерті Б.Брехта і побачила світ у 1967 році у постановці “Берлінер-ансамбль” 3 музикою німецького композитора, автора численних композицій у жанрах театральної, телевізійної та кіномузики (в тому числі до вистав в стилі “'зонгтеатру” Б.Брехта) Ганса-Дітера Хосалли (1919-1995). Працював над музичним оформленням і Д.Вагнер-Регені, але в силу обставин іiі здійснив Г.Д. Хозалла. Цікавою особливістю є те, що попри низку примітивних “зонгів-пісеньок”, композитор створює повнокровний розлогий симфонічний Вступ до п'єси, в якому перетворено не лише вже типові для “Турандот" маршові мотиви, але суттєво збільшені групи ударних та міді. Авангардові прийоми - алеаторика, інтенсивне використання додекафонної техніки, яскраві сонористичні ефекти перемежовуються у симфонічних фрагментах 3 популярними невибагливими пісеньками-зонгами. У 1981 "Берлінер ансамбль" виконує "Турандот" Брехта у постановці М. Векверта і Й. Теншерта 3 музикою Г.Д. Хозалли, записуючи при тім кілька музичних номерів на платівку.

В цюрихському «Шаушпільхаузе» брехтівськоа “Турандот” з'являється в 1969 р. 3 музикою одного 3 провідних світил авангардової музики Сzошуа Лякнера (1924-2003), соратником С. Кагеля та К. Штокгаузена. Цей неординарний композитор, окрім численних інструментальних експериментальних композицій активно працює в жанрі музики для авангардного театру 60-х років, переважно створюючи монтажні композиції зі стрічкою. Йому належить винахід специфічного стану музичної матерії, яку він назвав “музикою бетону" як своєрідної абстрактної стадії музики. Саме з такими гостро-авангардними пошуками Лякнер підійшов до створення музики до “Турандот" Б.Брехта. Очевидно, що під впливом естетики “очудження" народилася ця унікальна музична театральна композиція, де активно задіяні електроніка, конкретна музика, стрічка, які “гібридно” підкреслюють та актуалізують соціально-глобальну проблематику брехтівської Турандот.

Контроверсійне прочитання отримала брехтівська “Турандот” у Театрі на Таганці в Москві, реалізована у 1979 р. Юрісм Любімовим 3 музикою Альфреда Шнітке за участю співака-барда Володимира Висоцького. Гострополітична сатира викликала обурення владних структур, і незабаром п'єса була забороненою [11]. А. Шнітке написав 10 зонгів до цієї п'єси для чоловічого голосу і фортепіано з використанням гітари та акордеону. Так, музика А.Шнітке відрізнялася доволі похмурим характером, а у вокальній партії превалювали елементи декламації, підкреслені гармонічним мінорним нахилом бемольних тональностей (“Зонг про відрубані голови”, “Зонг про парасолю”, “Зонг про без вини винуватих”, "Голкотерапія”, “Пісня шарманщика", маршова "Патріотична пісня", "Рєшка", “Зонг про пісок”, притча “Наближається вік мій до схилу”, “Зонг про історичну ситуацію” з використанням секвенції Dies irae; солдатська пісня “Зонг про імператорську шинель» та заключна речитація "Випадок” в дусі заклинання). Побутова пісня і марш стають головними драматургічними виразниками, а подекуди вони співіснують одночасно. Пісні переважно будуються на типових інтонаційних зворотах, характерних для “блатних” андеграундних зразків, маршова ж складова виявляється у переважанні 4-дольної метрики та пунктирній ритміці, пронизаній паузами і синкопами (“Зонг при без вини винуватих”, “Голкотерапія", “Зонг про імператорську шинель”).

Майже через 10 років 1988-му Юрій Яценко склав із зонгів А.Шнітке концертну програму, яка звучала у супроводі фортепіано, і саме тоді зародилася ідея оркеструвати цю музику. Задум вдалося втілити в Україні в Київському театрі “Сузір'я” у 1998 р.. Участь в проекті взяли режисерка Лариса Паріс, композиторка Марина Денисенко, котра аранжувала клавір зонгів Шнітке та музиканти камерного оркестру під керівництвом Сергія Голубничого. Оригінальність прочитання полягала в тому, що класичні брехтівські зонги підлягли майстерній стилізації, замість віршованих текстів драматурга використано поезії А.Вознесенського та Б.Слуцького. Замість брехтівського соціального протесту, породженого реальністю 1930-40-х років, відчутний вплив андеграундної культури кінця 1970-х рр. Шнітківські мелодії на іронічно-патетичні тексти у дусі “дворових” пісень “працювали на рівень “відчуження”, який 3 боку сьогоднішньої естетики забезпечило аранжування М.Денисенко: оригінальна оркестровка, що виграє переважно за рахунок дерев'яних духових та ударних, навіть поза контекстом реальної вистави не дає шнітківським зонгам перейти у статус музичного антикваріату. У ролі музичного супроводу-відчуження було задіяно демонстрацію на кіноекрані уривків 3 фільмів В.Вендерса та Ф.Лянга, а також обличчя оркестрантів, композиторки М.Денисенко і диригента С.Голубничого, що диригував на тлі боксерського рингу [3]. 
Не менш радикальним був підхід до “Турандот” німецького драматурга Вольфганга Хільдесхаймера (1916-1991). Його обробка фаволи К. Гоцці має назву «Трон дракона» (1955) і створена під значним впливом «театру абсурду». Письменник, художник, неабиякий знавець музики, цей митець був речником нового театру абсурду та постмодернізму. Проте, його промова на відкритті Моцартівського фестивалю в Зальцбурзі «Що говорить музика?» захопила сучасників, а роман "Моцарт" (1977) став бестселером та основою для фільму “Амадеус" М.Формана. Абсолютна переверненість у всьому, застосування навіть сатири після трагедії - в такому “дикому” амплуа постає “перелицьована" Турандот, яка $є$ то катом, то жертвою, піднімаючи при тім в даному, до невпізнання спотвореному сюжеті, гострі соціальні, гуманістичні, гендерні проблеми. 3 музичної точки зору, оформлення цієї вистави мало риси кітчу та включало елементи геппенінгу, адже чудова музична обізнаність драматурга дозволили йому лучити музику найрізноманітніших стилів та епох, в тім - оригінальні записи автентичної китайської музики. Знаковий перформенс В.Хільдешмайєра, який здійснив свою квазігеппенінгову “Турандот” у вар'єте Штофф у 1955 р., отримав другу редакцію цієї мімо-театродрами у 1963 р. Варто додати, що попередньо "Принцеса Турандот" була здійснена як радіопостановка (Радіо-постановка на NWDR 29 січня 1954) досвід роботи в цьому жанрі автор отримав у співпраці з композитором Г.В. Хенце (радіоопера "Кінець світу" на NWDR 1953), у 1955 р. на радіо з'являється "Престол дракона", а у 1960 р. виходить нова версія літературномузичної театральої постановки “Завоювання принцеси Турандот”, в якій “незмінно-щасливе закінчення" змінюється на незбориму блокаду шлюбу героїні з принцом.

Примітно, що зовсім недавно, у 2017 р. в Україні на сцені Одеського академічного українського музично-драматичного театру імені В.Василька була поставлена «Турандот» Гоцці у режисурі Івана Уривського, Унікальність цієї постановки полягала в тому, що вперше даний сюжет зазвучав українською мовою (адаптував текст Гоцці Ігор Геращенко). Разом 3 балетмейстером Павлом Івлюшкіним автори запропонували по-суті хореографічну постановку, позбавлену декорацій, де пластична мімо-драма (комічний дель'артовий елемент знімається, і на сцені залишаються лише головні герої) з застосуванням колажу психоделічної музики та драматичної гри творить новий тип синтетичного дійства. I якщо скористатися даними музичної енциклопедії MGG [19, Р.220], в якій подано написання першої “Принцеси Китаю” 1717 р., то українська постановка 2017 р. може вповні вважатися приуроченою до 300річного ювілею цього непересічного і складного образу, який і донині хвилює митців.

Висновки. Таким чином, Турандот, пройшовши складний і насичений майже 300-річний шлях, насамперед виказала себе як один зі стійких образів на китайський сюжет, знаходячи своє прочитання у різнорідних музичних жанрах - театральній музиці, опері та іiі різновидах, оперетах, водевілях, мюзиклах, а також у балетному та інструментальному жанрах, входячи у XX-му столітті в сферу кіномузики та мультиплікації, кліпмейкерства. Стоячи біля витоків європейського екзотизму, зокрема, його китайського контенту, Турандот пройшла чи не всі стадії розвитку (барокового, класичного, романтичного, реалістичного, модернового) орієнталізму в європейській культурі - за Р. Локком та Е.Саїдом [24,31], виходячи на глобалістичний рівень у сфері міжкультурної комунікації. Також цей художній образ був адаптований і різноманітними театральними жанрами - починаючи від першопрочитання у бароковому ярмарковому театрі Форі Сен-Лорен у п'єсі ведучих драматургів лє Сажа та д'Орневаля з музикою Жан-Клода Жільє, італійській фаволі в стилі театру делль'арте К. Гоцці та їі романтичній німецькій інтерпретації Ф.Шіллєра, музику до вистав якого створили Ф. Дестуш, К.-М. Вебер (з інтерпретацією у ХХ ст. П.Гіндеміта), Й. Блюменталь, В. Ляхнер, демонструючи романтичний орієнталізм у жанрі театральної музики. Звернення до п'єси Гоцці та їі переосмислення в добу модернізму відбувається при прочитанні М. Рейнхарда та К.Вольмюллєра з музикою Ф.Бузоні, у шведського композитора В.Стенхаммара, бродвейському спектаклі Персі МакКея 3 музикою В.Ферста; у музиці до Харківської постановки п'єси Гоцці І.Дунаєвського (режисура В.Сінєльнікова), у “наївному театрі” Є.Вахтангова. Нове прочитання у дусі “епічного театру” отримала Турандот в творчості Б.Брехта, до посмертних постановок п'єси якого створили оригінальну сучасну музику Г.Д.Хосалла, Є.Ляхнер та А.Шнітке (у режисурі Ю.Любімова). Перезавантаження та оркестровка музики останнього відбулася в київській постановці театру “Сузір'я” - композитор М.Денисенко. Мімопластична експериментальна драма "Турандот" за К.Гоцці пройшла в 2017 р. в Одеському українському музично-драматичному театрі ім. В. Василька у режисурі I. Уривського та хореографа П. Івлюшкіна 3 використанням підбірки-колажу з фонової психоделічної сучасної музики, і що примітно - в адаптації І. Геращенка Турандот вперше зазвучала українською мовою. 


\section{ЛІТЕРАТУРА}

1. Брехт Б. Театр: Пьесы. Статьи. Высказывания: В 5 т. М.: Искусство, Т. 5/1. - 354 с.

2. Гоцци К. Турандот (перевод М.Лозинского) / Карло Гоцци. - С-Пб.:Азбука-классика, 2008., 215 с.

3. Денисенко М. Музика в театрі. Науковий вісник КМАУ ім.П.Чайковського: Композитор і сучасне соціокультурне середовище. - Вип.75, Київ, Родовід, 2009. с. 212-223.

4. Коган Г. М. Ферруччо Бузони. М.: Советский композитор, 1971. 217 с.

5. Кримський А. «Про 1001 день», «Изследования 1001 ночи» 8 вип. «Трудов по востоковедению, издаваем. Лазаревским институгом восточных языков», Низами и его современники: Элм, 1981, с.317-392.

6. Мищенко М. Творчество и эстетика Вильгельма Стенхаммара как феномен Скандинавской музыкальной культуры. Атореферат диссертации на соискание научной степени кандидата искусствоведения - 17.00.02 Санкт-Петербург, $1997-20$ с.

7. Низами Ганджеви. «Семь красавиц» (Перевод В. Державина), Собрание сочинений: В 5 т. Т.4 - М.: Художественная литература, 1986.

8. Смирнов-Несвицкий Ю. А. Вахтангов., Л., Искусство, 1987, 248 с. (с.191)

9. Сахновская-Панкеева А. Французский ярмарочный театр первой половины XVIII века: Ален-Рене Лесаж, Алексис Пирон, Шарль-Франсуа Панар (1999); диссертация на соискание научн. степени кандидата искусствоведения - 17.00.01- театральное искусство. Санкт-Петербург, 1999. 238 с.

10. Цырульник Е. Тема Востока во французской музыке: Автореф. дисс. канд. иск. М., 1985

11. Чигарева Е.И Художественный мир Альфреда Шнитке. М., 2001, С.236.

12. Шафер Н. Дунаєвский сегодня. М., “советский композитор", 1988, 275 с.

13. Шиллер Ф. Собр. соч., т. 6. М.: Искусство, 1957. С. 36-78.

14. Albert M. Les Théâtres de la Foire: (1660 1789). New York: B., Franklin, 1970. 312 p.

15. Ashbrook W., Powers H. (1991) Puccini's Turandot: the End of the Great Tradition.NJ: Princeton University Press

16. Barberet A.-V. Lesage et le théâtre de la foire. Genève: Slatkine reprints, $1970.266 \mathrm{p}$.

17. Busoni, F. Ueber die Moeglichkeiten der Oper ueber die Partitur des "Turandoht". Wiesbaden, Breitkopf \& Haertel, 1967.

18. Cucuel G. Sources et documents pour servir à l'histoire de l'Opéra-Comique en France // L'Année musicale. 1913. T. 3. P. $247-282$.

19. Die Musik in Geschichte und Gegenwart: allgemeine Enzyklopädie der Musik (2010), T. 7, Friedrich Blume, Ludwig Finscher, CA, p. 220

20. Fetis F.J. (1860) Biographie universelle des musiciens et bibliographie générale de la musique, T. 1, Didot.

21. Goldberg C. (1993) Sisters Turandot: A Study of the Folktale AT 851. York \& London: Garland Publishing, Inc.

22. Heulhard A. (1971) La' Foire Saint-Laurent, son histoire et ses spectacles. Genève: Slatkine reprints, 319 p.

23. Kim, Young Yun (2001) Becoming Intercultural: An Integrative Theory of Communication and Crosscultural Adaptation. CA: Sage Publication.

24. Locke Ralph P. (2009) Musical Exoticism: Images and ReflectionsCambridge University Press, 421 p.

25. L'Opéra-comique en France au XVIIle siècle (1992)/ Sous la direction de Ph. Vendrix. Liège: P. Mardaga, $377 \mathrm{p}$.

26. Le Théâtre De La Foire, Ou L'Opera Comique: Contenant Les Meilleures Pieces qui ont été représentées aux Foires de S. Germain \& de S. Laurent : Enrichies d'Estampes en Taille douce, avec une Table de tous les Vaudevilles et autres Airs gravez notez à la fin de chaque Volume. 7, 1 Gandouin, 1731 - 524 p.

27. Lurcel D. (1983) Le Théâtre de la foire au XVIII siècle. Paris: U.G.E. 480 p.

28. McCarthy, J. H. (1992) The Thousand and One days; Persian tales. London: Chatto \& Windus, 157 p.

29. Mann H. (1989) Die Musikerfamilie Lachner und die Stadt Rain (mit umfangreichem Verzeichnis von Quellen und Literatur), Rain 1989.

30. Rank E. "Turandet" MakKey, 1913 https://archive.org/details/athousandyearsa00mackgoog/page/n160

31. Said E. W. Orientalism. N. Y.: Pantheon Books, 1978. ХI, 368 p. (Русское издание: Саид Э. В.Ориентализм: западные концепции Востока / пер. с англ. и коммент. А. В. Говорунова,послесл. К. А. Крылова. Спб., Русский Мир, 2006. 637 с.)

32. Striker A. (1968) The Theatre of Alain-René Lesage: Dissertation. New York: Columbia University, 123 p.

33. Ward A. (2010) "Pagodas in Play: China on the Eighteenth century Italian Opera", 327 p. 